\title{
Novel Hydrido-Rhodium (III) Complexes with Some Schiff Bases Derived from Substituted Pyridines and Aryl Amines
}

Abdulhamid Alsaygh', Jehan Al-Humaidi ${ }^{2}$ and Ibrahim Al-Najjar ${ }^{1 *}$

${ }^{1}$ Petrochemicals Research Institute, King Abdulaziz city for Science and Technology, P.O.Box 6086, Riyadh, 11442, Kingdom of Saudi Arabia ${ }^{2}$ Chemistry Department, College of Science, Princes Nora Bent Abdulrahman University, Riyadh, Saudi Arabia

\begin{abstract}

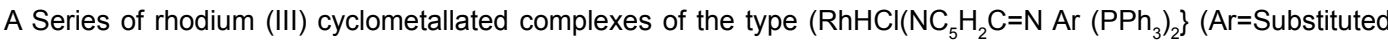
aryl), have been synthesized and characterized. Schiff bases derived from a substituted benzaldehyde and 2-amino pyridine substituents were allowed to react with $\left[\mathrm{RhCl}\left(\mathrm{PPh}_{3}\right)_{3}\right]$ or $[\mathrm{Rh}(\mu-\mathrm{Cl})(\mathrm{COD})]_{2}$ in the presence of 4 equivalents of $\mathrm{PPh}_{3}$ (or $\mathrm{Ph}_{2} \mathrm{BzP}$ ) to give $\mathrm{Rh}(\mathrm{III})$ Cyclometallated complexes, in which the imine $\mathrm{C}-\mathrm{H}$ bond was added oxidatively to the rhodium metal to give (H-M-C). The complexes were characterized using IR and NMR spectroscopy confirmed by elemental micro-analysis. The absorption of the hydride ligand was inferred as trans to $\mathrm{N}$-donar ligand.
\end{abstract}

Keywords: Rhodium; Schiff-bases; Phosphine complexes; Hydrido complexes; Oxidative-addition; Ligand substitution

\section{Introduction}

Although the Cyclometallation of aromatic and to a lesser extent aliphatic $\mathrm{C}-\mathrm{H}$ groups is widely recognized $[1,2]$, these are relatively little known concerning with the cyclometallation of aldehydes [3] and imine functions [4-6]. We have shown that Schiff bases of 2-substituted benzylideneaminothiazoles [5], and 2-(benzylideneamino) pyridines [6], can be form cyclometallated complexes at the imine carbon by using Rh (I) complex. A number of studies have exploited ligands such as quindine-8-carbaldehyde [3,7] and 2-(benzylideneamino) pyridines [8]. Complexation of the metal with aromatic nitrogen gives a favorable geometry for the insertion of the metal into the neighboring $\mathrm{C}-\mathrm{H}$ or $\mathrm{C}-\mathrm{C}$ bond $[4,7,9,10]$. In most recent application for ruthenium, rhodium and iridium complexes have been used as therapeutic agents and a number of kinetically inert ruthenium(II), iridium(III) and rhodium(III) complexes have been reported as inhibitors of protein kinases [11-15]. Chung-Hang Leung and Dik-Lung Ma group [14] has also actively pursued the development of kinetically inert metal complexes as inhibitors of various bimolecular targets, including DNA, enzymes and protein-protein interactions [13]. The synthesis and characterization of a variety of new rhodium (III) complexes of $\{\mathrm{N}$-benzylideneamino $\}$ pyridines, in which the imine $\mathrm{C}-\mathrm{H}$ bond has undergone oxidative addition to the metal, are reported here.

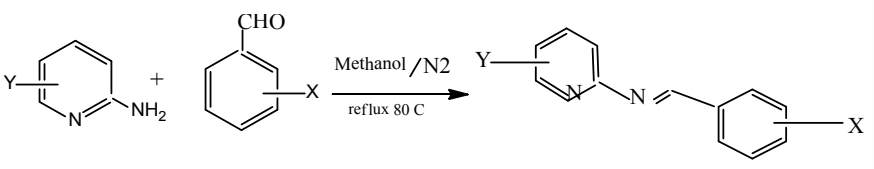

Scheme 1: Syntheses of Schiff's bases ligands.

\begin{tabular}{|c|c|c|c|c|c|}
\hline Complex No. & $\mathbf{Y}$ (pyridine) & $\mathbf{X}$ (aryl) & Complex No. & $\mathbf{Y}$ (pyridine) & $\mathbf{X}$ (aryl) \\
\hline 1. & $2-\mathrm{OH}$ & $\mathrm{H}$ & 8. & $4-\mathrm{NO}_{2}$ & $4-\mathrm{Me}$ \\
\hline 2. & $\mathrm{H}$ & $3-\mathrm{Me}$ & 9. & $4-\mathrm{Br}$ & $4-\mathrm{Me}$ \\
\hline 3. & $2-\mathrm{OH}$ & $3-\mathrm{Me}$ & 10. & $\mathrm{H}$ & $5-\mathrm{Cl}$ \\
\hline 4. & $4-\mathrm{NO}_{2}$ & $3-\mathrm{Me}$ & 11. & $2-\mathrm{OH}$ & $5-\mathrm{Cl}$ \\
\hline 5. & $4-\mathrm{Br}$ & $3-\mathrm{Me}$ & 12. & $4-\mathrm{NO}_{2}$ & $5-\mathrm{Cl}$ \\
\hline 6. & $\mathrm{H}$ & $4-\mathrm{Me}$ & 13. & $4-\mathrm{Br}$ & $5-\mathrm{Cl}$ \\
\hline 7. & $2-\mathrm{OH}$ & $4-\mathrm{Me}$ & & & \\
\hline
\end{tabular}

Table 1: The prepared Schiff bases (free ligands).

\section{Experimental}

\section{Materials and reagents}

All chemicals used such as pyridine substituent's, benzaldehyde substituent's, $\mathrm{RhCl}_{3} \mathrm{xH}_{2} \mathrm{O}$, phenyl phosphine $\left(\mathrm{PPh}_{3}\right)$ cyclo-1,5-octadiene (COD), tetrahydrofuran (THF), were obtained from Winlab, Aldrich Chemicals and Strem chemicals, respectively and were used without further purification.

\section{Instruments}

Open capillaries were used to determine melting points and were uncorrected using Gallenkamp Melting Points Apparatus. Elemental microanalysis of the separated solid chelates for $\mathrm{C}, \mathrm{H}, \mathrm{N}$, were performed at Perkin Elmer $2400 \mathrm{CHN}$. The analyses were repeated twice to check the accuracy of the results obtained. Infrared spectra were recorded on a Nexus 470-670-760 spectrometer and FT-IR Spectrometer, Spectrum 8400s. The ${ }^{1} \mathrm{H},{ }^{13} \mathrm{CNMR}$ and ${ }^{31} \mathrm{P}$ NMR spectra were recorded using 400 $\mathrm{MHz}$ Joel Spectrometer.

\section{Synthesis of ligands}

All experiments were carried out under an atmosphere of nitrogen by Schlenk techniques. The Schiff bases were prepared by mixing equivalent amount of substituted benzaldehydes and 2 -amino pyridine derivatives in methanol solution. This mixture was boiled under reflux with stirring for $8 \mathrm{~h}$, at $80^{\circ} \mathrm{C}$ in an oil bath, and then the mixture was concentrated by rotary evaporation to give yellow precipitate. Which was filtered off, dried, yields are $70 \%-80 \%$ (Scheme 1,Table 1). The results of UV, IR, ${ }^{1} \mathrm{H}$ and ${ }^{13} \mathrm{C}$, Spectroscopy and elemental analyses for Schiff's bases were published elsewhere [16].

Rhodium compounds of $\{\mathrm{RhCl}(\mathrm{COD})\}_{2}$ and $\left\{\mathrm{RhCl}\left(\mathrm{PPh}_{3}\right)_{3}\right\}$ were prepared by literature procedures $[17,18]$. In this work rhodium cyclometallated complexes, were prepared by the reaction of the Schiff

*Corresponding author: Ibrahim Al-Najjar, Petrochemicals Research Institute King Abdulaziz city for Science and Technology, P.O.Box 6086, Riyadh 11442 Kingdom of Saudi Arabia, Tel: 965-226-36626; E-mail: alnajjar@kacst.edu.sa

Received August 17, 2014; Accepted September 27, 2014; Published October 01,2014

Citation: Alsaygh A, Al-Humaidi J, Al-Najjar I (2014) Novel Hydrido-Rhodium (III) Complexes with Some Schiff Bases Derived from Substituted Pyridines and Aryl Amines. Mod Chem appl 2: 139. doi:10.4172/2329-6798.1000139

Copyright: $\odot 2014$ Alsaygh A, et al. This is an open-access article distributed under the terms of the Creative Commons Attribution License, which permits unrestricted use, distribution, and reproduction in any medium, provided the original author and source are credited. 


\begin{tabular}{|c|c|c|c|c|c|c|c|}
\hline Complex No. & $x$ & $\mathbf{Y}$ & $\mathbf{L}$ & Complex No. & $\mathbf{x}$ & $\mathbf{Y}$ & $\mathbf{L}$ \\
\hline 14. & $2-\mathrm{OH}$ & $\mathrm{H}$ & $\mathrm{BzPh}_{2} \mathrm{P}$ & 21. & $2-\mathrm{OH}$ & 4-Me & $\mathrm{PPh}_{3}$ \\
\hline 15. & $2-\mathrm{OH}$ & $\mathrm{H}$ & $\mathrm{PPh}_{3}$ & 22. & $4-\mathrm{NO}_{2}$ & 4-Me & $\mathrm{PPh}_{3}$ \\
\hline 16. & $\mathrm{H}$ & 3-Me & $\mathrm{PPh}_{3}$ & 23. & $4-\mathrm{Br}$ & 4-Me & $\mathrm{PPh}_{3}$ \\
\hline 17. & $2-\mathrm{OH}$ & 3-Me & $\mathrm{PPh}_{3}$ & 24. & $\mathrm{H}$ & $5-\mathrm{Cl}$ & $\mathrm{PPh}_{3}$ \\
\hline 18. & $4-\mathrm{NO}_{2}$ & 3-Me & $\mathrm{PPh}_{3}$ & 25. & $2-\mathrm{OH}$ & $5-\mathrm{Cl}$ & $\mathrm{PPh}_{3}$ \\
\hline 19. & $4-\mathrm{Br}$ & 3-Me & $\mathrm{PPh}_{3}$ & 26. & $4-\mathrm{NO}_{2}$ & $5-\mathrm{Cl}$ & $\mathrm{PPh}_{3}$ \\
\hline 20. & $\mathrm{H}$ & 4-Me & $\mathrm{PPh}_{3}$ & 27. & $4-\mathrm{Br}$ & $5-\mathrm{Cl}$ & $\mathrm{PPh}_{3}$ \\
\hline
\end{tabular}

Table 2: The prepared rhodium complexes (14-27).
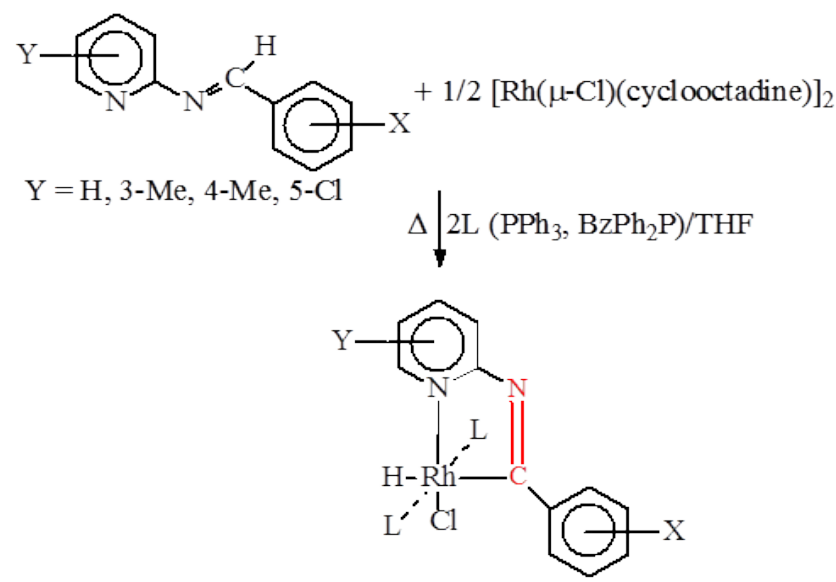

Scheme 2: Synthesis of rhodium complexes.

\begin{tabular}{|c|c|c|c|c|c|c|c|c|c|c|}
\hline \multirow{2}{*}{ No. } & \multirow{2}{*}{$\mathbf{L}$} & \multirow{2}{*}{$\mathbf{x}$} & \multirow{2}{*}{ M.P. $\left({ }^{\circ} \mathrm{C}\right)$} & \multirow{2}{*}{ M.F. } & \multicolumn{3}{|c|}{ Calculated (\%) } & \multicolumn{3}{|c|}{ Found (\%) } \\
\hline & & & & & C & H & $\mathbf{N}$ & C & $\mathbf{H}$ & $\mathbf{N}$ \\
\hline 14. & $\mathrm{Ph}_{2} \mathrm{BzP}$ & $2-\mathrm{OH}$ & 137 & $\mathrm{RhC}_{50} \mathrm{H}_{44} \mathrm{P}_{2} \mathrm{~N}_{2} \mathrm{OCl}$ & 67.53 & 5.34 & 3.15 & 67.66 & 5.23 & 3.34 \\
\hline 15. & $\mathrm{PPh}_{3}$ & $2-\mathrm{OH}$ & 225 & $\mathrm{RhC}_{48} \mathrm{H}_{4} 0 \mathrm{P}_{2} \mathrm{~N}_{2} \mathrm{OCl}$ & 66.94 & 4.68 & 3.25 & 67.30 & 4.89 & 3.21 \\
\hline 16. & $\mathrm{PPh}_{3}$ & $\mathrm{H}$ & 84 & $\mathrm{RhC}_{49} \mathrm{H}_{42} \mathrm{P}_{2} \mathrm{~N}_{2} \mathrm{Cl}$ & 68.49 & 4.92 & 3.26 & 68.28 & 4.71 & 3.47 \\
\hline 17. & $\mathrm{PPh}_{3}$ & $2-\mathrm{OH}$ & 100 & $\mathrm{RhC}_{49} \mathrm{H}_{42} \mathrm{P}_{2} \mathrm{~N}_{2} \mathrm{OCl}$ & 67.24 & 4.83 & 3.20 & 67.63 & 4.82 & 3.09 \\
\hline 18. & $\mathrm{PPh}_{3}$ & $4-\mathrm{NO}_{2}$ & 140 & $\mathrm{RhC}_{49} \mathrm{H}_{41} \mathrm{P}_{2} \mathrm{~N}_{3} \mathrm{O} 2 \mathrm{Cl}$ & 73.46 & 5.15 & 5.24 & 73.35 & 4.98 & 5.34 \\
\hline 19. & $\mathrm{PPh}_{3}$ & $4-\mathrm{Br}$ & 98 & $\mathrm{RhC}_{49} \mathrm{H}_{41} \mathrm{P}_{2} \mathrm{~N}_{2} \mathrm{BrCl}$ & 70.46 & 4.94 & 3.35 & 69.93 & 4.93 & 3.45 \\
\hline 20. & $\mathrm{PPh}_{3}$ & $\mathrm{H}$ & 98 & $\mathrm{RhC}_{49} \mathrm{H}_{42} \mathrm{P}_{2} \mathrm{~N}_{2} \mathrm{Cl}$ & 68.49 & 4.92 & 3.26 & 68.28 & 4.81 & 3.14 \\
\hline 21. & $\mathrm{PPh}_{3}$ & $2-\mathrm{OH}$ & 139 & $\mathrm{RhC}_{49} \mathrm{H}_{42} \mathrm{P}_{2} \mathrm{~N}_{2} \mathrm{OCl}$ & 67.24 & 4.83 & 3.2 & 66.93 & 4.86 & 3.34 \\
\hline 22. & $\mathrm{PPh}_{3}$ & $4-\mathrm{NO}_{2}$ & 155 & $\mathrm{RhC}_{49} \mathrm{H}_{41} \mathrm{P}_{2} \mathrm{~N}_{3} \mathrm{O} 2 \mathrm{Cl}$ & 73.44 & 5.15 & 5.24 & 73.35 & 5.01 & 5.35 \\
\hline 23. & $\mathrm{PPh}_{3}$ & $4-\mathrm{Br}$ & 97 & $\mathrm{RhC}_{49} \mathrm{H}_{41} \mathrm{P}_{2} \mathrm{~N}_{2} \mathrm{BrCl}$ & 70.46 & 4.94 & 3.35 & 70.33 & 4.53 & 3.13 \\
\hline 24. & $\mathrm{PPh}_{3}$ & $\mathrm{H}$ & 216 & $\mathrm{RhC}_{48} \mathrm{H}_{39} \mathrm{P}_{2} \mathrm{~N}_{2} \mathrm{Cl} 2$ & 64.40 & 4.46 & 3.18 & 64.53 & 4.43 & 3.28 \\
\hline 25. & $\mathrm{PPh}_{3}$ & $2-\mathrm{OH}$ & 349 & $\mathrm{RhC}_{48} \mathrm{H}_{39} \mathrm{P}_{2} \mathrm{~N}_{2} \mathrm{OCl} 2$ & 64.37 & 4.38 & 3.12 & 64.77 & 4.48 & 3.99 \\
\hline 26. & $\mathrm{PPh}_{3}$ & $4-\mathrm{NO}_{2}$ & 192 & $\mathrm{RhC}_{48} \mathrm{H}_{38} \mathrm{P}_{2} \mathrm{~N}_{3} \mathrm{O} 2 \mathrm{Cl} 2$ & 62.35 & 4.14 & 4.54 & 62.34 & 4.38 & 4.58 \\
\hline 27. & $\mathrm{PPh}_{3}$ & $4-\mathrm{Br}$ & 195 & $\mathrm{RhC}_{48} \mathrm{H}_{38} \mathrm{P}_{2} \mathrm{~N}_{2} \mathrm{BrCl}_{2}$ & 60.14 & 3.99 & 2.92 & 60.07 & 3.96 & 2.85 \\
\hline
\end{tabular}

Table 3: Physicochemical Properties of the rhodium complexes (14-27).

base with either $\left\{\mathrm{RhCl}\left(\mathrm{PPh}_{3}\right)\right\}$ or with $\{\mathrm{Rh}(\mu-\mathrm{C} 1)(\mathrm{COD})\}_{2}$. Two typical examples are described here.

1. A solution containing $\left\{\mathrm{RhCl}\left(\mathrm{PPh}_{3}\right)_{3}\right\}(300 \mathrm{mg}, 0.325 \mathrm{mmol})$ and an equivalent amount of Schiff base (in ca. $20 \mathrm{ml}$, of dry THF was boiled under reflux for $1 \mathrm{hr}$ under nitrogen atmosphere. After cooling, addition of $n$-hexane led to precipitation of the product as a yellow powder which was filtered off (the product recrystallized twice from $\mathrm{CH}_{2} \mathrm{Cl}_{2} /$ hexane, yield 40\%-50\% (Table 2 and Scheme 2).

2. A solution of $\{\mathrm{Rh}(\mu-\mathrm{C} 1)(\mathrm{COD})\}_{2}(200 \mathrm{mg}, 0.28 \mathrm{mmol})$ Schiff base $(0.56 \mathrm{mmol})$ and $\mathrm{PPh}_{3}(293 \mathrm{mg}, 1.12 \mathrm{mmol})$ in ca. $20 \mathrm{ml}$ of dry THF was boiled under reflux for $1 \mathrm{hr}$ addition of $\mathrm{n}$-hexane induced precipitation of the product, which was filtered off (the product could be recrystallized form $\mathrm{CH}_{2} \mathrm{Cl}_{2}$ /hexane (Table 2, Scheme 2).

\section{Results and Discussion}

The physical, analytical data and UV, IR, ${ }^{1} \mathrm{H},{ }^{13} \mathrm{C}$-NMR Spectroscopy for Schiff bases were published elsewhere [16]. The corresponding $\mathrm{Rh}$-complexes of different Schiff base ligand are investigated also by analytical, physical and different spectroscopy methods (Tables 3-5).

\section{Characterization of Rh-Complexes}

Infrared Spectra: Infrared spectra of the complexes were recorded to confirm their structure. The vibration frequencies and their tentative assignments for imines ligand (Scheme 1) and their Rh-complexes were assigned by comparison with the vibrational frequencies of the free ligand and their related complexes. The main futures in the infrared of the complexes is the shift of the stretching frequencies of the azomethine $(-\mathrm{C}=\mathrm{N}-)$ group of the transition metal complexes to lower frequencies 
Citation: Alsaygh A, Al-Humaidi J, Al-Najjar I (2014) Novel Hydrido-Rhodium (III) Complexes with Some Schiff Bases Derived from Substituted Pyridines and Aryl Amines. Mod Chem appl 2: 139. doi:10.4172/2329-6798.1000139

Page 3 of 9

\begin{tabular}{|c|c|c|c|c|c|c|c|c|}
\hline Complex No. & $\mathbf{x}$ & $\mathbf{Y}$ & $\mathbf{L}$ & $\delta^{1} \mathrm{H}$ Hydride (ppm) & $\delta^{31} \mathrm{P}\left\{{ }^{1} \mathrm{H}\right\}(\mathrm{ppm})$ & ${ }^{2} \mathrm{~J}\left({ }^{31} \mathrm{P}-{ }^{1} \mathrm{H}\right)(\mathrm{Hz})$ & ${ }^{1} \mathrm{~J}\left({ }^{103} \mathrm{Rh}-{ }^{1} \mathrm{H}\right)(\mathrm{Hz})$ & ${ }^{1} \mathrm{~J}\left({ }^{103} \mathrm{Rh}-{ }^{31} \mathrm{P}\right)(\mathrm{Hz})$ \\
\hline 14. & $2-\mathrm{OH}$ & $\mathrm{H}$ & $\mathrm{BzPh}_{2} \mathrm{P}$ & -11.78 & 25.6 & 11.00 & 14.3 & 105.0 \\
\hline 15. & $2-\mathrm{OH}$ & $\mathrm{H}$ & $\mathrm{PPh}_{3}$ & -11.43 & 30.2 & 11.00 & 13.2 & 112.0 \\
\hline 16. & $\mathrm{H}$ & 3-Me & $\mathrm{PPh}_{3}$ & -11.20 & 30.30 & 12.40 & 12.3 & 111 \\
\hline 17. & $2-\mathrm{OH}$ & 3-Me & $\mathrm{PPh}_{3}$ & -11.35 & 3069 & 12.42 & 12.4 & 112.5 \\
\hline 18. & $4-\mathrm{NO}_{2}$ & 3-Me & $\mathrm{PPh}_{3}$ & -11.21 & 30.63 & 12.45 & 13.7 & 114.5 \\
\hline 19. & $4-\mathrm{Br}$ & 3-Me & $\mathrm{PPh}_{3}$ & -11.27 & 30.65 & 12.44 & 13.3 & 114.3 \\
\hline 20. & $\mathrm{H}$ & 4-Me & $\mathrm{PPh}_{3}$ & -11.19 & 33.36 & 11.60 & 13.44 & 114.6 \\
\hline 21. & $2-\mathrm{OH}$ & 4-Me & $\mathrm{PPh}_{3}$ & -11.78 & 33.7 & 11.00 & 13.90 & 112.0 \\
\hline 22. & $4-\mathrm{OH}_{2}$ & 4-Me & $\mathrm{PPh}_{3}$ & -11.29 & 31.86 & $12 . .24$ & 13.44 & 114.6 \\
\hline 23. & $4-\mathrm{Br}$ & 4-Me & $\mathrm{PPh}_{3}$ & -11.32 & 32.69 & 11.00 & 12.20 & 118.0 \\
\hline 24. & $\mathrm{H}$ & $5-\mathrm{Cl}$ & $\mathrm{PPh}_{3}$ & $\begin{array}{r}11.19 \\
-11.19\end{array}$ & $\begin{array}{l}34.67 \\
18.79\end{array}$ & 11.20 & 13.41 & $\begin{array}{c}121.5 \\
98.7\end{array}$ \\
\hline 25. & $2-\mathrm{OH}$ & $5-\mathrm{Cl}$ & $\mathrm{PPh}_{3}$ & -11.41 & $\mathrm{n}$ & 11.23 & 14.10 & $n$ \\
\hline 26. & $4-\mathrm{NO}_{2}$ & $5-\mathrm{Cl}$ & $\mathrm{PPh}_{3}$ & -11.31 & $\mathrm{n}$ & 11.0 & 14.42 & $\mathrm{n}$ \\
\hline 27. & 4-Br & $5-\mathrm{Cl}$ & $\mathrm{PPh}_{3}$ & -11.32 & $\begin{array}{l}20.10 \\
26.82\end{array}$ & 11.30 & 14.52 & $\begin{array}{l}114.3 \\
104.3\end{array}$ \\
\hline
\end{tabular}

$\mathrm{n}=$ not measured

Table 4: ${ }^{1} \mathrm{H}$ and ${ }^{31} \mathrm{P}$ NMR $(\delta \mathrm{ppm})$ and coupling constants $(\mathrm{Hz})$ of the rhodium complexes $(14-27)$

\begin{tabular}{|c|c|c|c|}
\hline Complex No. & $\mathbf{X}$ & Y & 3 C(7) (ppm) \\
\hline 17. & $2-\mathrm{OH}$ & $3-\mathrm{Me}$ \\
\hline 18. & $2-\mathrm{NO}_{2}$ & 3-Me \\
\hline 19. & $4-\mathrm{Br}$ & $3-\mathrm{Me}$ \\
\hline 20. & $\mathrm{H}$ & $4-\mathrm{Me}$ \\
\hline
\end{tabular}

Table 5: ${ }^{13} \mathrm{C}-\mathrm{NMR}$ for iminoyl carbon $(\mathrm{C}-7)(\delta \mathrm{ppm})$ in the rhodium complexes $(17-20)$.

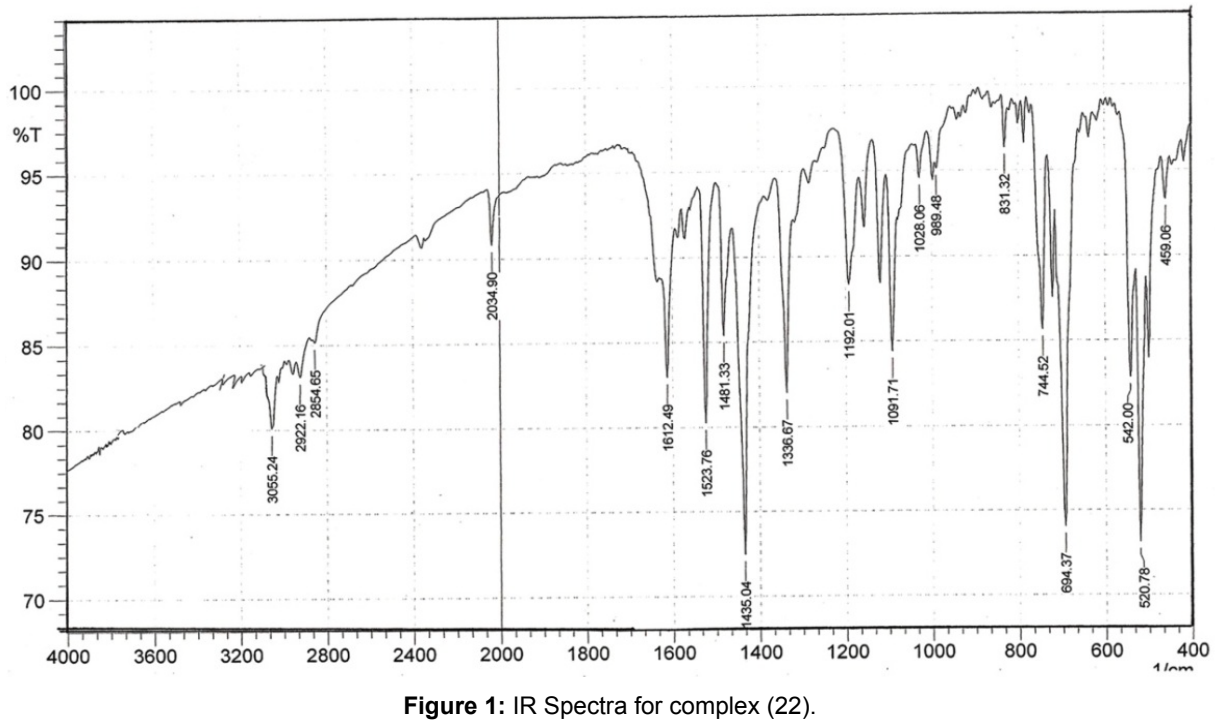

in the range, $1600-1576 \mathrm{~cm}^{-1}$, compared with free imine ligand, $\mathrm{v}(1690$ $\left.1620 \mathrm{~cm}^{-1}\right)$ due to the coordination of the azomethine moiety, $\mathrm{v}(\mathrm{C}=\mathrm{N})$ to the metal [19]. Further evidence of the bonding is given by the observation of new bands in the spectra of the metal complexes of medium or week intensity at the region $467-435 \mathrm{~cm}^{-1}$ due to $\mathrm{v}(\mathrm{M}-\mathrm{N})$ stretching vibration supporting the involvement of the nitrogen atom of the azomethine group via coordination [20,21] (Figure 1), complex (22). Further evidence come from the spectra of ${ }^{1} \mathrm{H},{ }^{13} \mathrm{C}$ and ${ }^{31} \mathrm{P}$ NMR (Tables 4 and 5).

${ }^{1} \mathrm{H},{ }^{13} \mathrm{C}$ and ${ }^{31} \mathrm{P}$ NMR Spectra: The ${ }^{1} \mathrm{H},{ }^{13} \mathrm{C}$ and ${ }^{31} \mathrm{P}$ NMR spectra of the rhodium complexes have been studied in $\mathrm{CDCl}_{3}$. The ${ }^{1} \mathrm{H}$ NMR spectrum of each of the new rhodium complexes in $\mathrm{CDCl}_{3}$, shows a hydride resonance between $\delta 11.19-11.78 \mathrm{ppm}$ (Table 4$)$. The imines $\mathrm{C}-\mathrm{H}$ signals for the starting free imines appear at $\delta$ 9.01-9.44 ppm and after complexation these signals are absent, providing evidence for insertion of $\mathrm{Rh}$ metal into the $\mathrm{C}-\mathrm{H}$ bond of the imines. Strong confirmation evidence comes from appearance of the resonance of the hydride signal in each complex at high field [22,23], ca. (average) $\delta$ $-11.29 \mathrm{ppm}$. The hydride signals in the complexes are split by compiling to two equivalent ${ }^{31} \mathrm{P}$ nuclei of the rhodium complex. As both of these spin-spin couplings are ca. $11.00-14.52 \mathrm{~Hz}$, frequently. ${ }^{1} \mathrm{~J}\left({ }^{103} \mathrm{Rh}-{ }^{1} \mathrm{H}\right) . \mathrm{Hz}$, and $2 \mathrm{~J}\left({ }^{31} \mathrm{P}-{ }^{1} \mathrm{H}\right)$, ca. $11.00-12.45 \mathrm{~Hz}$ (Table 4). The hydride multiple often appears as a pseudo quartet, but at higher resolution studies usually reveal the expected doublet of triplets (Figure 2 and Figure $3)$, complexes (23 and 24). The phosphine $\left(\mathrm{PPh}_{3}\right)$ rhodium complexes 

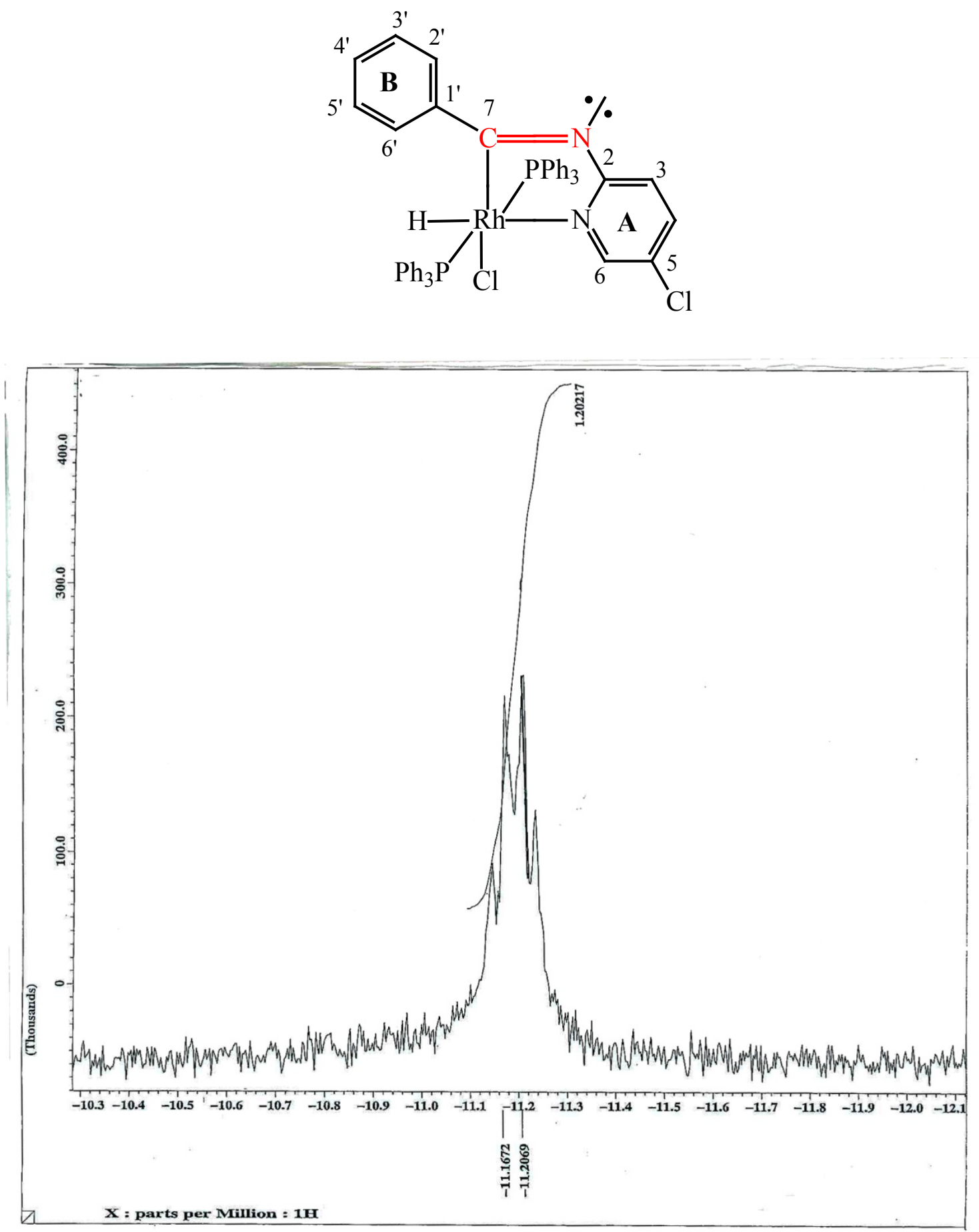

Figure 2: ${ }^{1} \mathrm{H}$ NMR (hydride) spectra for complex (23).

(Figure 4 and Figure 5), complexes (24 and 27), show a ${ }^{31} \mathrm{P}$ signal at ca. 18.79-34.67 Hz, (Table 4), with ${ }^{1} \mathrm{~J}\left({ }^{103} \mathrm{Rh}-{ }^{31} \mathrm{P}\right) 98.7-118.0 \mathrm{~Hz}$ as a doublet in keeping with previous report $[3,10,16]$, depending on the type of the substituent group on pyridine ring (Table 4 ). The majority of the rhodium imine hydride complexes are only moderately soluble in most organic solvents. The signal of ${ }^{13} \mathrm{C}=\mathrm{N}$ of the imino group is observed at ca. $\delta$ 225.06-237.60ppm (Table 5). The ${ }^{13} \mathrm{C}\left[{ }^{1} \mathrm{H}\right] \mathrm{NMR}$ spectrum, in particular the signal from the metal-bonded carbon atom, is consistent with the presence of the cyclometallated ring $[22,23]$. The signal from the metal-bonded carbon, C(7) (iminoyl carbon), appear as a doublet or triplets owing to coupling of two equivalent ${ }^{31} \mathrm{P}$ nuclei and the ${ }^{103} \mathrm{Rh}$ nucleus, whereas the corresponding signal from the uncomplexed imines is found at ca. $\delta 146.24-164.97 \mathrm{ppm}$ [22]. This low-field position for $\mathrm{C}(7)$ has been observed in other cases in what a chelating atom is incorporated in a five member-ring [24], and is not unusual for a cyclometallated $\mathrm{sp}^{2}$ carbon [25], similar to carbenecarbon. The remaining ${ }^{1} \mathrm{H}$ and ${ }^{13} \mathrm{C}$ data are as expected. Steric effects are extremely important to structures, spectroscopic properties, and 

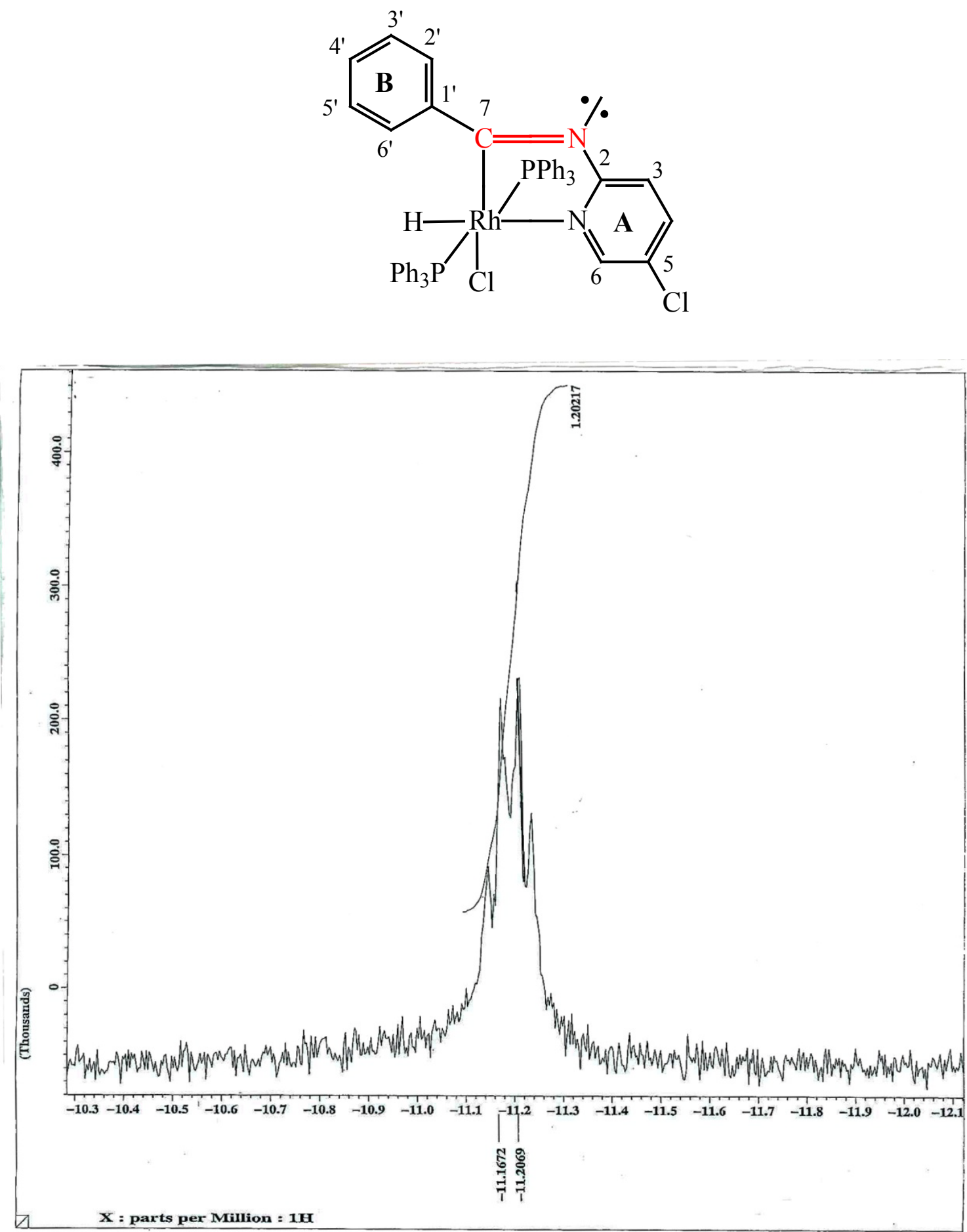

Figure 3: ${ }^{1} \mathrm{H}$ NMR (hydride) spectra for complex [24].

chemical behavior of phosphorus ligands and their complexes [26]. In this study two types of phosphorus ligands $\left(\mathrm{PPh}_{3}\right.$ and $\left.\mathrm{PBzPh}_{2}\right)$ were used with different steric and electronic effects. The cone-angle data of Tolman [27] allows some comparisons of relative ligand steric effects to be made and demonstrates phosphine ligands such as $\mathrm{PBzPh}_{2}$ (ca. $153^{\circ}$ ) and $\mathrm{PPh}_{3}\left(\mathrm{ca} .145^{\circ}\right)$. Increasing the size of the substituents on phosphorus will tend to reduce the s character in the phosphorus long pair, thus decreasing ${ }^{1} \mathrm{~J}(\mathrm{M}-\mathrm{P})[21]$. Data from Table 5, shows the $\delta^{31} \mathrm{P}$ $\left[{ }^{1} \mathrm{H}\right]$ at $25.60 \mathrm{ppm}$, with ${ }^{1} \mathrm{~J}\left({ }^{103} \mathrm{Rh}-{ }^{31} \mathrm{P}\right), 112.0 \mathrm{~Hz}$ when ligand $\mathrm{BzPh} 2 \mathrm{P}$ and $\delta^{31} \mathrm{P}\left[{ }^{1} \mathrm{H}\right]$ at $105.0 \mathrm{~Hz}$ with ${ }^{1} \mathrm{~J}\left({ }^{103} \mathrm{Rh}-{ }^{31} \mathrm{P}\right), 105.0 \mathrm{~Hz}$ when ligand $\mathrm{PPh}_{3}$ $[27,28]$.

The position of the ligand signals in both IR(v Rh-H, $2034.9 \mathrm{~cm}$ $\left.{ }^{1}\right)$ for complex 22 (Figure 1$)$ and ${ }^{1} \mathrm{H}-\mathrm{NMR}(\delta-11.29 \mathrm{ppm})$ Spectra, are as expected for a $\mathrm{Rh}-\mathrm{H}$ bond trans to $\mathrm{N}$-donor ligand. Furthermore, 

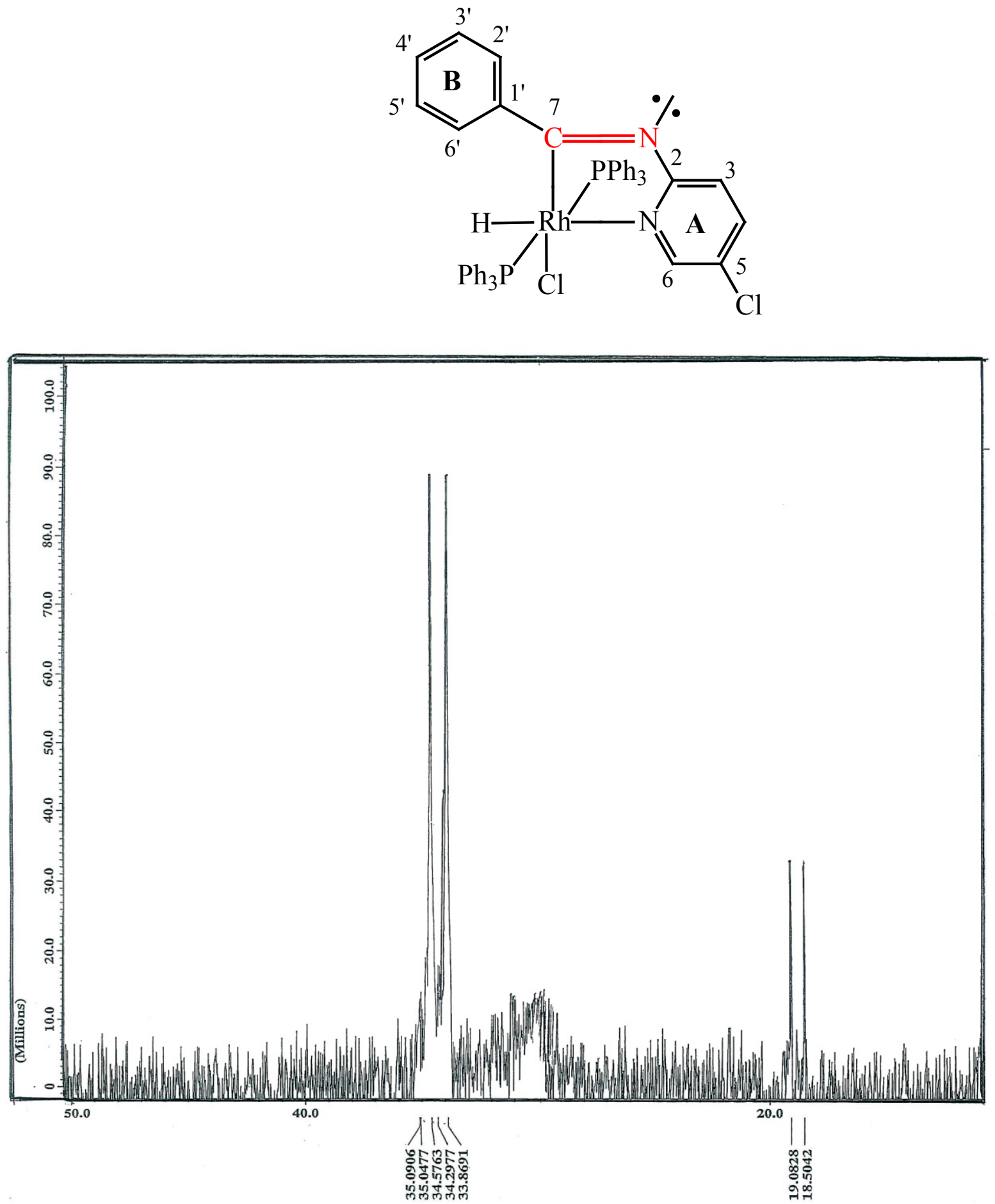

Figure 4: ${ }^{31} \mathrm{P}$ NMR spectra for complex (24).

the ${ }^{1} \mathrm{~J}\left({ }^{31} \mathrm{P}-1 \mathrm{H}\right)$ value is consistent with a hydride located cis to two magnetically equivalent $\mathrm{PPh}_{3}$ groups [29], which in turn are mutually trans, as inferred from ${ }^{31} \mathrm{P}\left[{ }^{1} \mathrm{H}\right] \mathrm{NMR}$ spectrum (Table 4).

Interestingly, the hydride and ${ }^{31} \mathrm{P}$ NMR spectrum of complexes 24 and 27 , the ${ }^{31} \mathrm{P}-\mathrm{NMR}$ presented in two types of spectrum, for ${ }^{31} \mathrm{P}-\mathrm{NMR}$ spectra, which $\delta$-observed at 34.67 and 18.79 ppm (for complex 24), and at $\delta 20.10$ and $26.82 \mathrm{ppm}$ (for complex 27), with ${ }^{2} \mathrm{~J}\left({ }^{31} \mathrm{P}-{ }^{1} \mathrm{H}\right) 11.20 \mathrm{~Hz}$ and $11.30 \mathrm{~Hz}$, (Figure 4 and Figure 5) respectively, and with ${ }^{1} \mathrm{~J}\left({ }^{103} \mathrm{Rh}-\right.$ ${ }^{31} \mathrm{P}$ ), of $121.50 \mathrm{~Hz}, 98.70 \mathrm{~Hz}$ and $121.50,104.2 \mathrm{~Hz}$ respectively (Table 4).

This result may be due to complex instability. The similarity of present of $\mathrm{Cl}$ - atom at $\mathrm{C} 5$ results of two or three ${ }^{31} \mathrm{P}$ absorption spectrum. By substitution of Br-atom at C-4 of aryl ring (Figure 5) a significant change in signal of ${ }^{31} \mathrm{P}$ was recorded in Figures 4,5 and Table 4. It was also observed that the signal for $\mathrm{C}-7$ (iminoyl carbon ${ }^{13} \mathrm{C}=\mathrm{N}$ ) is 

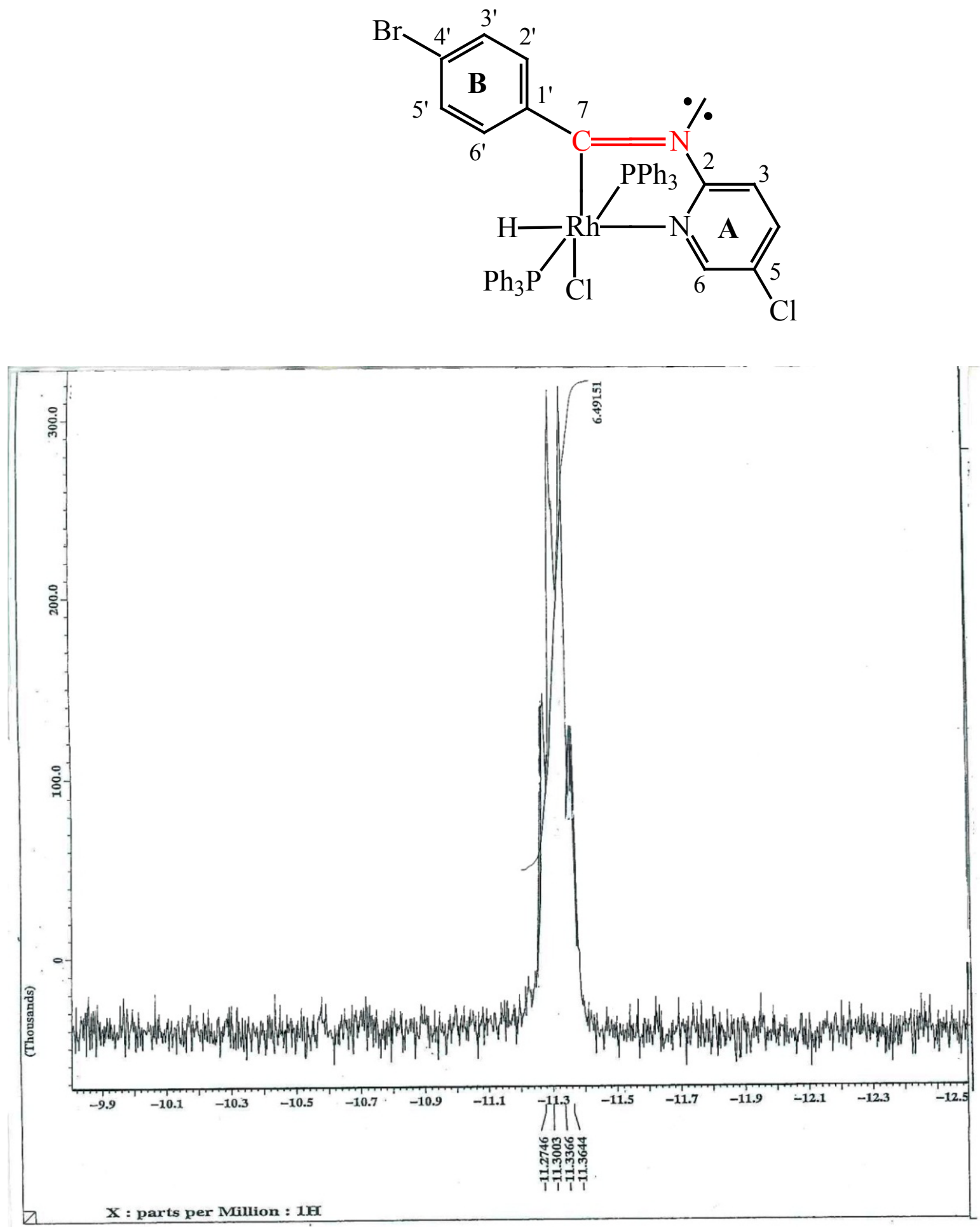

Figure 5: ${ }^{1} \mathrm{H}$ NMR spectra for complex (27).

at low magnetic field, at $\delta 225.16-237.60 \mathrm{ppm}$ with ${ }^{1} \mathrm{~J}\left({ }^{103} \mathrm{Rh}-{ }^{13} \mathrm{C}\right), 32-33$ $\mathrm{Hz}$ and ${ }^{2} \mathrm{~J}\left({ }^{31} \mathrm{P}-{ }^{13} \mathrm{C}\right), 8-9 \mathrm{~Hz}$ (Table 5).

The rhodium complexes are only moderately soluble in organic solvents, and so we have not obtained many ${ }^{13} \mathrm{C}$ spectra, however, some ${ }^{13} \mathrm{C}(7)$ data for few complexes are shown in Table 5 . The signal for C-7 is all at 225.16-237.60 ppm, whereas the uncomplexed imines C-7 signal is found at $\delta 159.39-164.97 \mathrm{ppm}$. This low field position is suggestive of carbine-like properties; however, the $\delta{ }^{13} \mathrm{C}=\mathrm{N}$ for complex (24) is observed at low magnetic field at $\delta 237.67 \mathrm{ppm}$ (Table 5 and Figure 6).

Unfortunately, treatment of some of imines prepared in this work 

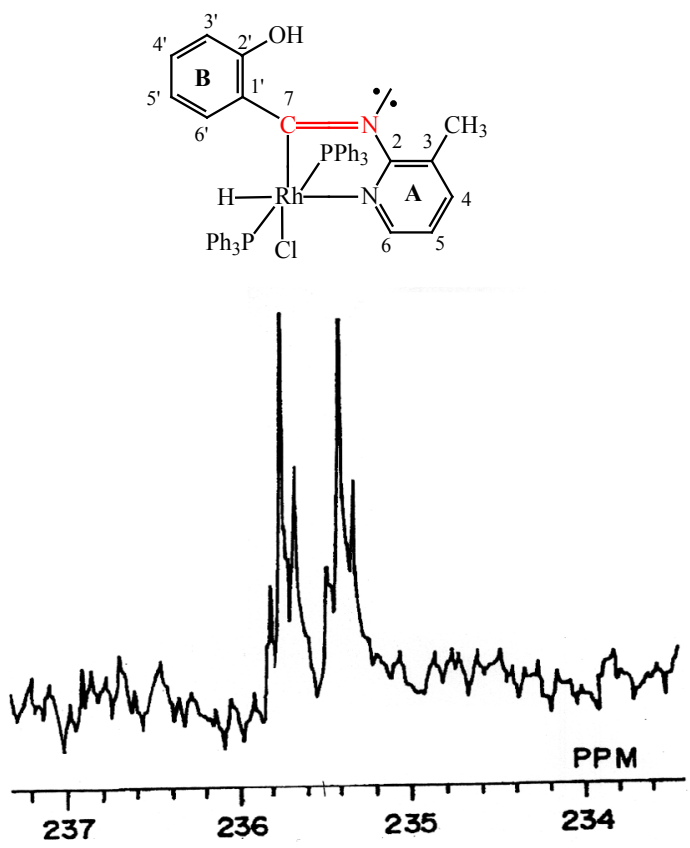

Figure 6: 13C-NMR spectra for complex (17).

with 1,5 -hexadiene in toluene at $110^{\circ} \mathrm{C}$ for $6 \mathrm{~h}$ under $\left[\mathrm{RhCl}\left(\mathrm{PPh}_{3}\right)_{3}\right]$ in screw-capped vial, gives only imonoacyl rhodium(III) complex. The chromatographic results show no indication of forming hex-5enylketimine. These results indicated that the bond between rhodium and hydrogen is not active enough, very stable and can't go for further reactions.

\section{Conclusion}

The new cyclometallated rhodium complexes have been characterized by elemental analysis, UV, IR, ${ }^{1} \mathrm{H},{ }^{31} \mathrm{P}$ (occasionally) and ${ }^{13} \mathrm{C}$-NMR-spectroscopy. Interestingly the hydride ligand signal in IR (v $2034.9 \mathrm{~cm}^{-1}$ and ${ }^{1} \mathrm{H}-\mathrm{NMR}(\delta-11.29 \mathrm{ppm}$ ), complex (22). The result obtained from the spectra was expected for $\mathrm{Rh}-\mathrm{H}$ group trans position to the $\mathrm{N}$-donor ligand.

However, the ${ }^{31} \mathrm{P}-\mathrm{NMR}$ for some cyclometallated complexes shows signal at $\delta 31.86 \mathrm{ppm}$, complex (22). Furthermore, the ${ }^{2} \mathrm{~J}\left({ }^{31} \mathrm{P}-1 \mathrm{H}\right)$ value account for $\mathrm{H}$ cis to two magnetically equivalent $\mathrm{PPh}_{3}$-groups, which in turn are mutually trans, as inferred from ${ }^{31} \mathrm{P}(1 \mathrm{H})$ NMR spectrum. This result is supported from ${ }^{1} \mathrm{H}$ and ${ }^{13} \mathrm{C}$ NMR spectra.

Interestingly, the ${ }^{13} \mathrm{C}-\mathrm{NMR}$ of the iminoyl carbon $\left({ }^{13} \mathrm{C}=\mathrm{N}\right)$ signal in $\mathrm{Rh}(\mathrm{III})(\delta$ 225.16-237.60 ppm). This low-field position for cyclometallated complexes is suggestive of carbene-like properties. The result from the study indicated that the bond between rhodium and hydrogen is not active enough, very stable and can't go for further reactions.

\section{Acknowledgement}

The author would like to thank the Research Centre, College of Science, Princess Nora Bent Abdulrahman University and King Abdulaziz city for Science and Technology for the financial support to this research project (AT-17-171).

\section{References}

1. Constable EC (1984) Cyclometallated complexes incorporating a heterocyclic donor atom; the interface of coordination chemistry and organometallic chemistry. Polyhedron 3: 1037-1057.
2. Bruce MI (1977) Cyclometalation Reactions.Angewandte Chemie International Edition in English 16: 73-86.

3. Albinati A, Anklin CG, Ganazzoli F, Ruegg H, Pregosin PS (1987) Preparative and proton NMR spectroscopic studies on palladium(II) and platinum(II) quinoline-8-carbaldehyde (1) complexes. X-ray structures of the cyclometalated acyl complex $\mathrm{PdCl}(\mathrm{C}(\mathrm{O}) \mathrm{C} 9 \mathrm{H} 6 \mathrm{~N}) \mathrm{PPh} 3)$.cntdot.PPh3 and trans-PtCl2(Q)(PEt3). Inorg Chem 26: 503-508.

4. Albinati A, Arz C, Pregosin PS (1987) Synthesis, structure and NMR spectroscopy of some rhodium(III) cyclometallated Schiff's base complexes derived from 2-benzylidene-3-methylpyridines. Crystal structure of [RhHI\{2(3-nitrobenzylidene)-3-methylpyridine\}; $\left(\mathrm{PPh}_{3}\right)_{2}$ ]. Journal of Organometallic Chemistry 335: 379-394.

5. El-Baih FEM, Abu-Loha FM, Gomma Z, Al-Najjar IM (1994) Synthesis and characterization of some rhodium(III) cyclometallated complexes of 2-substituted benzylideneamino thiazoles. Transition Metal Chemistry 19: 325 328

6. Amin HB (1997) Synthesis and Characterization of Some Rhodium (III) CyclometallatedSchiff's Base Complexes Derived from 2-Benzylidene Amino substituted Pyridines.J King Saud University, Science 9: 65-75.

7. Suggs JW, Wovkulich MJ, Cox SD (1985) Synthesis, structure, and ligand-promoted reductive elimination in an acylrhodium ethyl complex. Organometallics 4: 1101-1107.

8. Suggs JW (1979) Activation of aldehyde carbon-hydrogen bonds to oxidative addition via formation of 3-methyl-2-aminopyridyl aldimines and related compounds: rhodium based catalytic hydroacylation. J Am Chem Soc 101: 489-493.

9. Suggs JW, Jun $\mathrm{CH}$ (1985) Metal-catalysed alkyl ketone to ethyl ketone conversions in chelating ketones via carbon-carbon bond cleavage. J Chem Soc Chem Commun 92-93.

10. Meiswinkel A, Werner H (2004) Five- and six-coordinate hydridorhodium(III) complexes containing metalated Schiff-bases as ligands.InorganicaChimica Acta 357: 2855-2862.

11. Leung $\mathrm{CH}$, He HZ, Liu LJ, Wang M, Chan DSH, et al. (2013) Metal complexes as inhibitors of transcription factor activity.Coordination Chemistry Reviews 257: 3139-3151.

12. Zhong HJ, Leung KH, Liu LJ, Lu L, Chan DS, et al. (2014) Antagonism of mTOR Activity by a Kinetically Inert Rhodium(III) Complex. ChemPlusChem79: 508511.

13. Liu LJ, Lin S, Chan DS, Vong CT, Hoi PM, et al. (2014) A rhodium(III) complex inhibits LPS-induced nitric oxide production and angiogenic activity in cellulo. $J$ Inorg Biochem 140C: 23-28.

14. Ma DL, Liu LJ, Leung KH, Chen YT, Zhong HJ, et al. (2014) Antagonizing STAT3 Dimerization with a Rhodium(III) Complex.Angew Chem Int Ed Engl 53: $9178-9182$.

15. Leung $\mathrm{CH}$, Yang H, Ma VPY, Chan DSH, Zhong HJ, et al. (2012) Inhibition of Janus kinase 2 by cyclometalated rhodium complexes.Med Chem Commun 3: 696-698.

16. Alsaygh A, Al-Humaidi J, Al-Najiar I (2014) Synthesis of Some New Pyridine2-yl-Benzylidene-IminesInternational Journal of Organic Chemistry 4: 116-121.

17. Colquhoun HM, Holton J, Thompson DJ, Twigg MV (1984) New Pathways for Organic Synthesis: Practical Applications of Transition Metals. Springer Press Science.

18. Osborn JA, Wilkinson G (1967) Tris (triphenylphosphine) halorhodium(I) Inorganic Syntheses 10: 67-71.

19. Nakamoto K(1997) Infrared and Raman Spectra at Inorganic and Coordination Components ( $5^{\text {th }}$ edition). John Wiley and Sons, New York.

20. Chohan HZ, Naseer MM (2007) Organometallic based biologically active compounds: synthesis of mono- and di-ethanolamine derived ferrocenes with antibacterial, antifungal and cytotoxic properties.Applied Organometallic Chemistry 21: 1005-1012.

21. El-Shiekh SM, Abd-Elzaher MM, Eweis M (2006) Synthesis, characterization and biocidal studies of new ferrocenylthiadiazolo-triazinone complexes.Applied Organometallic Chemistry 20: 505-511.

22. Dowerah D, Radonovich LJ, Woolsey JF, Heeg MJ (1990) Reaction of 2-((. alpha.-R-benzylidene)amino)pyridines $\left[\mathrm{R}=\mathrm{CH}_{3}, 4-\left(\mathrm{CH}_{3} \mathrm{O}\right) \mathrm{C}_{6} \mathrm{H}_{4}\right]$ with $\mathrm{RhCl}(\mathrm{L}) 3$ or $\mathrm{Rh}_{2} \mathrm{Cl}_{2}(\mathrm{CO})_{4}$ : formation and structure of a rhodium(II) dimer. Organometallics 9: 614-620. 
Citation: Alsaygh A, Al-Humaidi J, Al-Najjar I (2014) Novel Hydrido-Rhodium (III) Complexes with Some Schiff Bases Derived from Substituted Pyridines and Aryl Amines. Mod Chem appl 2: 139. doi:10.4172/2329-6798.1000139

23. Suggs JW, Chul-Ho J (1984) Directed cleavage of carbon-carbon bonds by transition metals: the $\alpha$-bonds of ketones. J Am Chem Soc 106: 3054-3056.

24. Giordano G, Crabtree RH (1979) Preparation of (1,5-cyclooctadiene) chlororhodium (I) dimer; rhodium complex. Inorganic Syntheses 19: 218-220.

25. Garrou PE (1981) DELTA.R-ring contributions to phosphorus-31 NMR parameters of transition-metal-phosphorus chelate complexes. Chem Rev 81 : 229-266.

26. Foot RG, Heaton BT (1973) Metallation of 2-vinylpyridine by rhodium (III). J Chem Soc ChemCommun838-839.
27. Tolman CA (1977) Steric effects of phosphorus ligands in organometallic chemistry and homogeneous catalysis. Chem Rev 77: 313-348.

28. Al-Najjar IM (1987) ${ }^{31} \mathrm{P}$ and ${ }^{195} \mathrm{Pt}$ NMR characteristics of new binuclear complexes of $\left.\left[\mathrm{Pt}_{2} \mathrm{X}_{4}\right]\left(\mathrm{PR}_{3}\right)_{2}\right]$ cis/trans isomers and of mononuclear analogs. InorganicaChimica Acta 128: 93-104.

29. Kaesz HD, Sailant RB (1972) Hydride complexes of the transition metals. Chem Rev 72: 231-281. 